\title{
Выбор модели управления городом как фактор консолидации городских сообществ (на примере административных центров регионов Черноземья)
}

\author{
Слатинов В.Б. \\ Курский государственный университет, \\ Россия, 305000, г. Курск, ул. Радищева, 33 \\ E-mail: slatinov@yandex.ru
}

\begin{abstract}
Аннотация. Важными факторами успешной консолидации городских сообществ являются высокий уровень легитимности системы управления, а также вовлеченность граждан в процесс формирования и ротации исполнительной власти города. Несколько волн муниципальных реформ в России с начала 2000-х годов сформировали тенденцию к встраиванию местного самоуправления в вертикаль власти. В управлении региональными столицами областей Центрального Черноземья доминируют модели, в которых исполнительная власть города формируется при деятельном участии исполнительной власти субъекта Федерации и доминирующих групп интересов. Отчужденность горожан от процесса формирования исполнительных структур городской власти препятствует усилиям по социальной консолидации местных сообществ.
\end{abstract}

Ключевые слова: управление городом, мэр, выборы, губернатор, публичная власть, консолидация.

Для цитирования: Слатинов В.Б. 2021. Выбор модели управления городом как фактор консолидации городских сообществ (на примере административных центров регионов Черноземья). NOMOTHETIKA: Философия. Социология. Право, 46 (4): 794-798. DOI: $10.52575 / 2712-746 \mathrm{X}-2021-46-4-794-798$

\section{The Choice of a City Management Model as a Factor of Consolidation of Urban Communities (on the Example of the Administrative Centers of the Chernozem Regions)}

\author{
Vladimir B. Slatinov \\ Kursk State University, \\ 33 Radishcheva St, Kursk 305000, Russian Federation \\ E-mail: slatinov@yandex.ru
}

Annotation. Important factors for the successful consolidation of urban communities are the high level of
legitimacy of the management system, as well as the involvement of citizens in the process of formation
and rotation of the executive power of the city. Several waves of municipal reforms in Russia since the
beginning of the 2000 s have formed a tendency to embed local self-government in the "vertical of
power". The management of the regional capitals of the regions of the Central Chernozem region is
dominated by models in which the executive power of the city is formed with the active participation of
the executive power of the subject of the Federation and the dominant interest groups. The alienation of 
citizens from the process of forming executive structures of the city government hinders efforts to consolidate local communities socially.

Keywords: city management, mayor, elections, governor, public power, consolidation.

For citation: Slatinov V.B. 2021. The Choice of a City Management Model as a Factor of Consolidation of Urban Communities (on the Example of the Administrative Centers of the Chernozem Regions). NOMOTHETIKA: Philosophy. Sociology. Law, 46(4): 794-798 (in Russian). DOI: 10.52575/2712746X-2021-46-4-794-798

Анализ и активное публичное обсуждение проблем социальной консолидации городских сообществ сегодня протекают не только в условиях масштабных изменений социальной структуры современных городов, включая углубление ее этнической, имущественной и культурной дифференциации [Бабинцев, 2016, с. 47], но и в ситуации глубоких институциональных изменений в организации местной власти в современной России, ставших следствием нескольких волн муниципальных реформ. Магистральным направлением трансформации института местного самоуправления, начиная с первой половины 2000-х годов, является его встраивание в формирующуюся и укрепляющуюся вертикаль власти [Туровский, 2015, с. 48].

В регионах Центрального Черноземья вертикализация муниципального уровня публичной власти стартовала с начала реализации ФЗ № 131 «Об общих принципах организации местного самоуправления в РФ», то есть с 2003 года. На первом этапе из предложенных трех вариантов организации власти в областных центрах макрорегиона распространялась модель с сити-менеджером - на нее в течение 2003-2013 годов перешли Белгород, Курск и Тамбов. После предоставления в 2014 году в рамках малой муниципальной реформы права регионам императивно определять особенности систем управления муниципалитетами, выборность населением глав городов была отменена в Липецкой области. Последним «бастионом» среди чернозёмных региональных столиц, где сохранялись прямые выборы градоначальника населением, оставался Воронеж. Но в декабре 2016 года гордума Воронежа внесла поправки в Устав города, отменив прямые выборы. Таким образом, к началу 2017 года все региональные административные центры областей Центрального Черноземья перешли от модели с выбираемым населением «сильным» (одно лицо занимает позицию главы города и главы администрации) мэром к вариантам, где мэра избирают депутаты [Слатинов, Меркулова, 2017, с. 129].

Как уже отмечалось, организация систем управления региональными столицами с 2003 по 2015 годы насчитывали три варианта, предложенных в 131-Ф3, среди которых наиболее подходящим для региональной исполнительной власти с точки зрения ее влияния на управление городом и осуществления контроля над исполнительной властью областного центра был вариант с избранием главы города из состава депутатов представительного органа и последующим наймом после конкурсного отбора главы администрации (сити-менеджера). Модель с сити-менеджером позволяла в максимальной мере встроить муниципальную исполнительную власть областного центра в вертикаль через участие представителей областной власти в конкурсной комиссии по отбору кандидатов в главы администрации, а также через депутатское большинство «Единой России» в городском представительном органе. Надо отметить, что в областных центрах регионов Черноземья случаи фрагментации единороссовского большинства, позволяющие отдельным политическим игрокам реализовывать автономные стратегии противодействия креатурам губернаторов, не отмечались. Возможно, это стало фактором широкого распространения в Черноземье феномена «заместителя губернатора по областному центру» - когда на должность 
главы администрации региональной столицы направлялся заместитель главы региона в 2005 году таковым стал Максим Косенков в Тамбове, в 2008 году - Николай Овчаров в Курске, в 2011 и в 2019 году - Сергей Боженов и Юрий Галдун в Белгороде, в 2015 году Сергей Иванов в Липецке. Ключевая проблема функционирования модели управления городом с сити-менеджером состояла в том, что главой муниципального образования являлся руководитель представительного органа, таким образом глава администрации (он же креатура губернатора) был отчасти ослаблен с точки зрения полномочий. «Разделенное правление» (между формальным главой города и главой администрации) не проявлялось в случаях с областными центрами Черноземья в конфликтной форме (в других регионах эти проявления наличествовали), однако относительная институциональная слабость главы администрации представляла из себя проблему, которая была решена в 2015 году, когда поправки в 131-Ф3 добавили к трем действующим моделям управления муниципалитетами еще две, в том числе ту, в которой должности главы муниципального образования и главы администрации совмещались, но для должностного лица на подобной статусной позиции более не требовалось избрания населением - оно избиралось депутатами после прохождения конкурсного отбора, как и в случае с сити-менеджером. Так была закреплена модель, где «сильный» мэр избирался не горожанами, а депутатами после прохождения предварительного «фильтра» в лице конкурсной комиссии, половину состава которой назначает высшее должностное лицо субъекта Российской Федерации.

Указанная модель в максимальной мере удовлетворяет задаче установления политикоадминистративного контроля областной власти за муниципальным уровнем. В системе управления городом появляется фигура с консолидированными властными полномочиями, в отборе которой прямо - через делегированных представителей в отборочную комиссию, и косвенно - через единороссовское большинство в представительном органе - участвует областная исполнительная власть. Неслучайно, именно на эту модель с 2015 года перешли все региональные столицы областей Центрального Черноземья, кроме Белгорода, в котором сохранилась модель с сити-менеджером [Слатинов, Меркулова, 2017, с. 123].

Сложившиеся в административных центрах регионов Черноземья модели городского управления отвечают нескольким базовым требованиям, присущим современной российской политической системе. Во-первых, в них преобладают вертикальный политический контроль и вертикальная подотчетность между городским и региональным уровнями публичной власти. Во-вторых, основными акторами городской политики в такой институциональной конфигурации систем управления городами становятся региональная власть и наиболее влиятельные группы интересов, представленные в депутатском корпусе либо способные повлиять на решения депутатов. Формирование исполнительной власти города полностью находится в руках указанных игроков, к ним же направлена подотчетность мэра и городской администрации.

Констатируя органичную встроенность господствующих в региональных столицах Черноземья моделей управления в общенациональную вертикаль, официальный дискурс утверждает, что переход к выборам глав городов депутатами представительных органов после конкурсного отбора позволяет: (1) обеспечить привлечение на должности мэров профессиональных управленцев, или, по меньшей мере, лиц, соответствующих по своим компетенциям задачам муниципального управления, в то время как выборы глав городов населением создают риски избрания популистов и малокомпетентных политиков; (2) стабилизировать процесс функционирования органов власти городов, уменьшить риски флуктуаций муниципального управления вследствие некомпетентности, популизма либо избыточного влияния заинтересованных групп. Исследования реальных практик функционирования новых моделей управления городами, однако, показывают, что достижение 
указанных целей либо не происходит, либо, в лучшем случае, наблюдается эффект «частичных улучшений».

Анализ политико-управленческих результатов внедрения новых моделей управления областными центрами в регионах Черноземья, проведенный нами за 2015-2020 годы, демонстрирует, что носители компетенций в сфере муниципального управления далеко не всегда оказываются на должностях мэров региональных столиц. При этом избрание в 2019 году губернаторами Липецкой и Курской областей представителей так называемой «новой волны» региональных руководителей, сопровождавшееся сменой глав областных центров, укрепило, скорее, противоположную тенденцию - в качестве новых мэров были утверждены: представительница бизнеса, не имевшая опыта публичного управления (Е. Уваркина, Липецк ${ }^{1}$ и профессиональный политик - депутат Государственной Думы (В. Карамышев, Курск) ${ }^{2}$. В городе Тамбов с 2015 года по 2020 год (срок полномочий губернатора Александра Никитина) сменилось три мэра (все они были креатурами главы региона), а на выборах в городскую думу в 2020 году «Единая Россия» потерпела сокрушительное поражение от партии «Родина», региональное отделение которого возглавлял бывший сити-менеджер города Максим Косенков. Губернатор был вынужден пойти на компромисс с региональным отделением «Родины» и его лидером, лично предложив Максиму Косенкову временно возглавить город. При этом претендовать на выборную должность мэра города Косенков не может в связи с имевшейся судимостью, поэтому для его утверждения в статусе градоначальника требуется возвращение для областного центра модели управления с сити-менеджером. Право на изменение порядка формирования органов власти муниципалитетов закреплено за областным парламентом, поэтому между новым временно исполняющим обязанности мэра Тамбова и губернатором региона, очевидно, заключен политический компромисс ${ }^{3}$. Как видим, наличие «вертикального» порядка формирования и функционирования муниципальной власти в городе Тамбов не исключило политико-управленческих флуктуаций, в которые погрузилась система городского управления.

Отчуждение населения от процесса формирования исполнительной власти города существенным образом затрудняет возможности консолидации городских сообществ, способствует фрагментации городской политико-управленческой среды, в которой обостряются противоречия между влиятельными игроками, имеющими доступ к избранию (назначению) главы исполнительной власти городского округа (областная власть и наиболее влиятельные заинтересованные группы), и остальным населением города. В таких условиях обостряется борьба за формирование и преобразование городского пространства, а также по другим чувствительным проблемам городской политики [Тыканова, 2016. с. 365]. Попытки компенсировать дефицит легитимности исполнительной власти города и отчуждение населения от процессов ее формирования и ротации через развитие механизмов обратной связи посредством использования социальных сетей, а также через вовлечение горожан в выработку и контроль за реализацией городских проектов и программ (включая стратегию городского развития) представляются перспективной, но половинчатой мерой. Предпочтительной траекторией развития местного самоуправления в городах является общая децентрализация полномочий публичной власти, параметров и механиз-

\footnotetext{
${ }^{1}$ Мэром Липецка избрана Евгения Уваркина. URL: https://gorod48.ru/news/1842844/ (дата обращения: 15. 06. 2021).

${ }^{2}$ Новый мэром Курска избран депутат Госдумы Виктор Карамышев. URL: https: //www.rbc.ru/chr/20/06/2019/5d0ba6919a794751117dfcfe (дата обращения: 15. 06. 2021).

${ }^{3}$ Прах А. Александру Никитину придется «Родину» любить. URL: https://www. kommersant.ru/doc/4492408 (дата обращения: 15. 06. 2021).
} 
мов налогового и бюджетного обеспечения ее уровней, рост автономии местной власти, сохранение вариативности выбора моделей управления в муниципалитетах при доминирующем движении в направлении расширения практик выборов мэров крупных городов. Однако наблюдаемые траектория и характер эволюции системы публичной власти в стране исключают подобный сценарий, по меньшей мере, в краткосрочной перспективе.

\section{Список литературы}

1. Бабинцев В.П. 2016. Проблемы консолидации местных сообществ. Вестник института социологии, 2 (17): 46-65. DOI: 10.19181/vis.2016.17.2.396

2. Слатинов В.Б., Меркулова К.Г. 2017. Погружение в «вертикаль»: трансформация статуса и кадрового состава глав административных центров регионов Черноземья в условиях «малой» муниципальной реформы. Среднерусский вестник общественных наук, 5: 122-130. DOI: 10.22394/2071-2367-2017-12-5-122-130

3. Туровский Р.Ф. 2015. Российское местное самоуправление: агент государственной власти в ловушке недофинансирования и гражданской пассивности. Полис. Политические исследования, 2: 35-51. DOI: 10.17976/jpps/2015.02.03

4. Тыканова Е.В. 2016. Консолидация локальных сообществ в ситуации оспаривания городского пространства Санкт-Петербурга. Петербургская социология сегодня, 7: 364-388.

\section{References}

1. Babintsev V.P. 2016. The Problems of Consolidation in Local Communities. Bulletin of the Institute of Sociology, 2 (17): 46-65 (in Russian). DOI: 10.19181/vis.2016.17.2.396

2. Slatinov V. B., Merkulova K. G. 2017. Pogruzhenie v «vertikal'»: transformatsiya statusa i kadrovogo sostava glav administrativnykh tsentrov regionov Chernozem'ya v usloviyakh «maloI» munitsipal'noi reformy. [Immersion in the "vertical": transformation of the status and personnel composition of the heads of administrative centers of the Chernozem regions in the conditions of "small " municipal reform]. Srednerusskii vestnik obshchestvennykh nauk, 5: 122-130. DOI: 10.22394/20712367-2017-12-5-122-130

3. Turovsky R.F. 2015. Russia's Local Self-Government: the Agent of the Government in the Trap of Insufficient Funding and Civil Passivity. POLIS. Political Studies, 2: 35-51 (in Russian). DOI: 10.17976/jpps/2015.02.03

4. Tykanova E.V. 2016. Konsolidatsiya lokal'nykh soobshchestv v situatsii osparivaniya gorodskogo prostranstva Sankt-Peterburga. [Consolidation of local communities in the situation of challenging the urban space of St. Petersburg]. Peterburgskaya sotsiologiya segodnya, 7: 364-388.

Конфликт интересов: о потенциальном конфликте интересов не сообщалось.

Conflict of interest: no potential conflict of interest related to this article was reported.

\section{ИНФОРМАЦИЯ ОБ АВТОРЕ}

Слатинов Владимир Борисович, доктор политических наук, доцент, директор института экономики и управления, заведующий кафедрой государственного и муниципального управления Курского государственного университета, г. Курск, Россия

\section{INFORMATION ABOUT THE AUTHOR}

Vladimir B. Slatinov, Doctor of Political Science, Associate Professor, Director of the Institute of Economics and Management, Head of the Department of State and Municipal Administration, Kursk State University, Kursk, Russia 